\title{
Retail Changes and Consumption Practices in the Neighbourhood of Vomero, Naples
}

Citation: L. D'Alessandro, A. Autiero (2020). Retail Changes and Consumption Practices in the Neighbourhood of Vomero, Naples. Bollettino della Società Geografica Italiana serie 14, 3 Special Issue: 25-35. doi: 10.36253/ bsgi-1008

Copyright: (c) 2020 L. D'Alessandro, A. Autiero. This is an open access, peerreviewed article published by Firenze University Press (http://www.fupress. com/bsgi) and distributed under the terms of the Creative Commons Attribution License, which permits unrestricted use, distribution, and reproduction in any medium, provided the original author and source are credited.

Data Availability Statement: All relevant data are within the paper and its Supporting Information files.

Competing Interests: The Author(s) declare(s) no conflict of interest.

For Italian evaluation purposes: While the article was a group effort, paragraphs 1,2, and 4 are attributed to Libera D'Alessandro and paragraphs 3, 3.1, and 3.2 are attributed to Annachiara Autiero.

\section{Mutamenti del commercio e pratiche di consumo nel quartiere Vomero a Napoli}

\author{
Libera D’Alessandro, Annachiara Autiero \\ Dipartimento di Scienze Umane e Sociali, Università di Napoli "L'Orientale" \\ E-mail: ldalessandro@unior.it; aautiero@unior.it
}

\begin{abstract}
The article focuses on the Neapolitan neighbourhood of Vomero, whose most recent transformations can be effectively read through the lenses of retail and consumption geography. In greater detail, the evolution of the neighbourhood will be briefly outlined through a long-lasting look on its retail change, from its urbanization to the current configuration of a fabric modified by new consumption practices, in turn generated by the different demands of (old and new) inhabitants and users. The fieldwork research, which took place on a selected core-area and was articulated into various moments - site visits, with the emotions and perceptions they aroused; mapping, to reconstruct the spatial organisation of retail and entertainment activities; indepth interviews with privileged witnesses; analysis of local commercial policies - will allow to exemplify how the neighbourhood escapes the simplicity of some urban thesis on local-global dialectic. Even in a micro-space which has been the symbol of innovation and separation from the rest of Naples, the commercial core is disputed among various actors. At the scale of the polarizing nodes of the neighbourhood, the retail changes and the consumption practices - although not induced by top-down project or branding policies - highlight new tensions between forms of innovation and of embeddedness.
\end{abstract}

Keywords: innovations, embeddedness, retail changes, consumption practices, neighbourhood.

Riassunto. Larticolo è focalizzato sul quartiere napoletano del Vomero, le cui più recenti trasformazioni possono essere lette efficacemente attraverso la lente della geografia del commercio e del consumo. Più in dettaglio, l'evoluzione del quartiere sarà brevemente delineata attraverso uno sguardo di lunga durata sul suo mutamento commerciale, dall'urbanizzazione fino all'attuale configurazione di un tessuto modificato dalle nuove pratiche di consumo, a loro volta generate dalle diverse esigenze di (vecchi e nuovi) abitanti e utilizzatori. La ricerca sul campo, che si è concentrata su unarea centrale ed è stata articolata in vari momenti - sopralluoghi, con le emozioni e le percezioni che hanno suscitato; mappatura, per ricostruire l'organizzazione spaziale delle attività commerciali e di intrattenimento; interviste in profondità con testimoni privilegiati; analisi delle politiche commerciali locali - consentirà di esemplificare il modo in cui il quartiere sfugge alla semplicità di alcune tesi urbane sulla dialettica locale-globale. Anche in un micro-spazio che è stato il simbolo dell'innovazione e della separazione 
dal resto di Napoli, il nucleo commerciale è oggetto di contese tra vari attori. Alla scala dei nodi polarizzanti del quartiere, i mutamenti del commercio e le pratiche di consumo - sebbene non indotti da progetti top-down o da politiche di branding evidenziano nuove tensioni tra forme di innovazione e di radicamento.

Parole chiave: innovazioni, radicamento, cambiamenti del commercio, pratiche di consumo, quartiere.

\section{Introduction}

As a theoretical point of reference, this contribution lies on the branch of urban studies that considers retail and consumption as interpretative keys of changes within cities, and that has been developed in various manners, depending on the different analytical contexts ${ }^{1}$. Recently, said branch of research has also constituted one of the starting points of a Research Project of Relevant National Interest (Italian acronym PRIN), in which we have participated, focused on the role that retail activities and dynamics of consumption have in redesigning Italian urban landscapes (Viganoni 2017, 2019).

In the context of the extensive debate that has developed thanks to the contribution of geographical studies in the English language, urban areas appear amongst the principle topics, to be considered as the context for new ways of interpreting the geographies of retail and consumption (Lowe, Wrigley 2000, 641). This renewed attention is fruit of the recognition of the close interdependence that exists between economic and cultural variables both in the area of retail and consumption geography, as well as in terms of surmounting the barriers between this discipline and the other social sciences (D’Alessandro 2012).

Since the mid-Nineties, studies on "micro-geographies" that modified the spatiality of retail and consumption have challenged the more simplistic theses regarding globalization (Crewe, Lowe 1995). The neighbourhood, in that respect, seemed the micro-space particularly suited to exemplify the urban-retail change that, in turn, often represented the result of consumption preferences and changes in the property dynamics, rather than the product of macro-visions of urban planners $^{2}$ (Ibidem 1887). This perspective seems to focus on

\footnotetext{
${ }^{1}$ For more information, reference should be made to the bibliographic repertory elaborated by Carreras, D'Alessandro 2017.

2 As to the importance of the scale of the neighbourhood, see the multidisciplinary overview in Bell, Jayne 2004.
}

that which still occurs today in the Neapolitan neighbourhood of Vomero. The change in this micro-space, although not brought about by top-down projects or branding policies, has recently nonetheless generated controversial effects. These will be explored with the aid of fieldwork, in the belief that this case study can offer useful elements for the interpretation of several dynamics that characterize Naples ${ }^{3}$.

From symbol of modernization in the recent past, this neighbourhood continues to represent a sort of avant-garde in terms of retail and entertainment, as demonstrated by the diffusion of new formats and the spread of their corresponding consumption practices especially in the fields of fast fashion and food, that in Vomero evolve in different manners as compared to other areas of the city. The transformations caused by the proliferation of new activities, on one hand, contribute to bringing about new innovations in the urban fabric but, on the other hand, seem to challenge the urban holding capacity of the same fabric, so contributing to a progressive homogenization of the retail landscape. The fieldwork, together with references to the most significant policies, will allow for the exemplification as to how - even at the micro-space scale that has been the outpost of modernization initially, and then of innovations - Naples is difficult to situate in simplistic interpretations of the relationship between globalization and places. Retracing some of the most significant transitions that have marked the long-time relationship between retail activities and Vomero will contribute to making evident the characteristics of the neighbourhood as a "differentiated space of consumption" (Crewe, Lowe 1995, 1877). Though renewal and autonomy with respect to the rest of the city have always been distinctive features of the Vomero, the places on which we have decided to focus our attention have recently undergone further changes, which seem harbingers of certain types of renewal and, at the same time, of unprecedented consequences in terms of embeddedness: both are dimensions that can be interpreted in an even more effective manner through the magnifying glass of retail and consumption.

\footnotetext{
${ }^{3}$ As to more general aspects of the relationship between retail, consumption and city at the Neapolitan urban and metropolitan scale, see the article by Sommella, D'Alessandro in this special issue.
} 


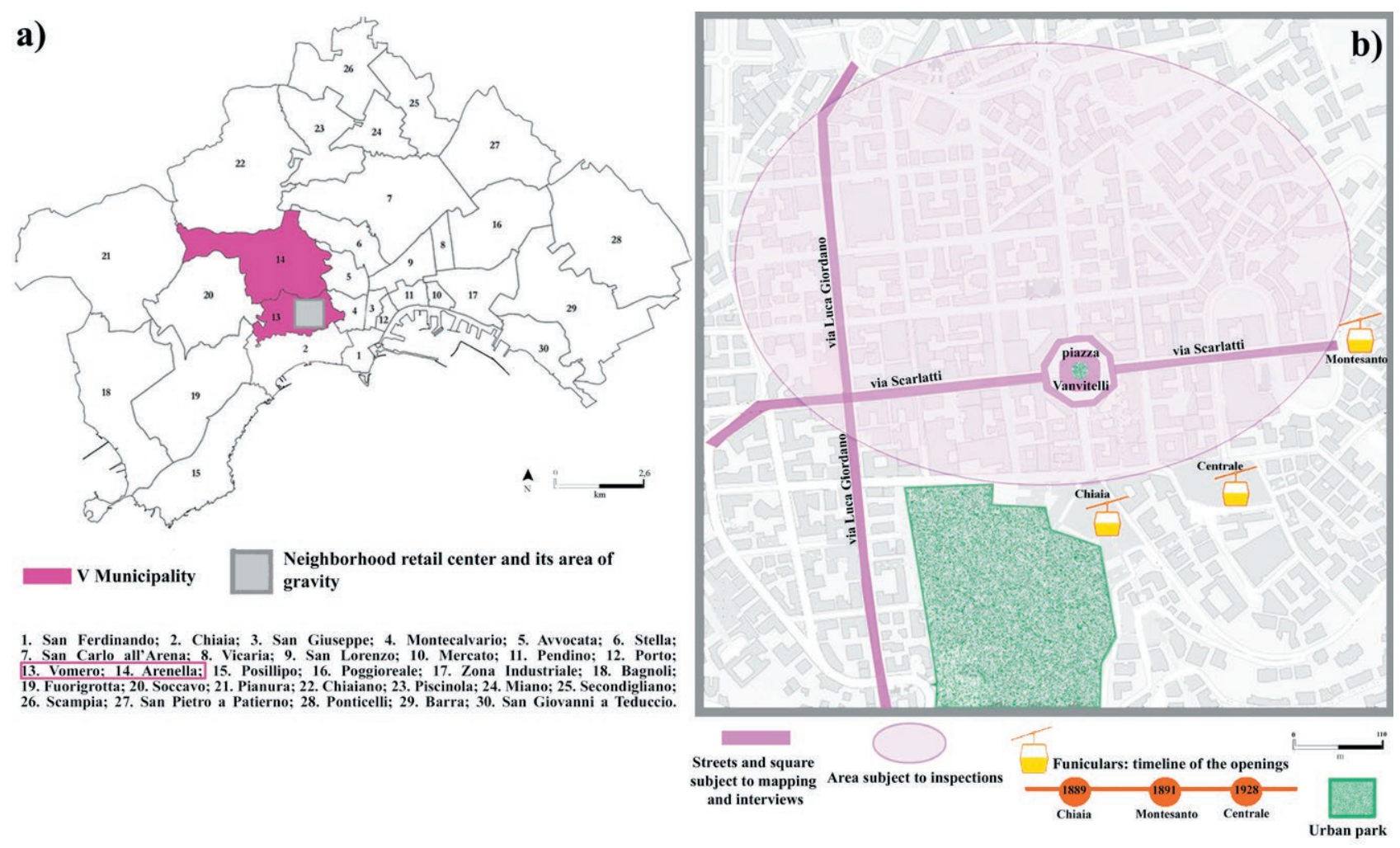

Figure 1. The Vomero neighborhood: a) position and administrative boundaries; b) the perimeter of the fieldwork. Source: authors' elaboration.

\section{A micro-space as a symbol of commercial modernization}

Vomero and Arenella ${ }^{4}$ - neighborhoods developed in the hills, northeast of the city center - make up the Fifth Municipality ${ }^{5}$. The former still revolves around its traditional commercial hub, which still today boasts a vast area of gravitation, considered overall as the perimeter of our research (Fig. 1).

This hub has its area of concentration in the retail street Alessandro Scarlatti: besides being defined as the

\footnotetext{
${ }^{4}$ In a research on the residential localization of upper classes, the two hilltop neighborhoods were defined as élite spaces, expanding mainly in the Fifties and Sixties of the past century (Pfirsch 2011). Actually if we consider a certain type of retail and consumption in addition to localization - it is above all the Vomero that, since its urbanization, has become "an integral part of the city as a new area of bourgeois settlement" (La Gala 2004, 91): the neighborhood has taken shape as an élite space, with its core in the area we have taken into consideration.

${ }^{5}$ As of 2016 the Municipality, which spans an area of 7.4 square kilometers, had a resident population of about 112,000 inhabitants and a population density of 15,135 inhabitants/square kilometer. As to the Vomero neighborhood specifically, as of 31 December, 2016 (the last data available on the website of the Municipal Authority), the resident population totaled 44,422 inhabitants, highlighting a decrease of $4.8 \%$ compared to 2010 (http://www.comune.napoli.it/flex/cm/pages/ServeBLOB.php/L/IT/ IDPagina/34362, last accessed on 7/5/2020).
}

"main street" since the creation of the so-called "rione Vomero" (La Gala 2004, 94), it has been designated through the years as one of its cornerstones, together with piazza Vanvitelli (the square that crosses the aforementioned street) and the two Funicular Railways of Chiaia and Montesanto ${ }^{6}$, to which the Central Funicular Railway was added some decades later ${ }^{7}$. The other street object of the current mapping is via Luca Giordano: while its main stretch was also central in the past ${ }^{8}$, now

${ }^{6}$ As La Gala states, the Banca Tiberina - that had received the concession from the Municipality for the urbanization of the Vomero neighborhood (and for that of Arenella, realized later) - had considered those connections of fundamental importance in order to allow the pioneering inhabitants to "go up to the new neighborhood" when it was still practically desertified from a commercial standpoint (Idem).

7 The study, carried out by two Neapolitan engineers around 1880 to create mechanical transportation systems with a cableway installation, aimed to "connect the Vomero neighborhood to the lower western area (the Chiaia Funicular) and to the city center (the Montesanto Funicular)"; the installation of the Central Funicular occurred in the 1920s, when the need for a new form of connection between the neighborhood and the city center became pressing, also due to the insufficient service of the two installations constructed previously (http://www.anm.it/index.php?option=com content\&task=view\&id=341\&Itemid=100, last accessed on 7/5/2020).

${ }^{8}$ Together with via Scarlatti, during the years following WWII, via Luca Giordano became - in the spaces left vacant between buildings - home 
the street features new locations for retail activities and food, even in its extensions.

Between the end of the 1800s and the beginning of the 1900s, the neighborhood was characterized by numerous possibilities from the urban-commercial point of view: a regulated relationship between the height of buildings and the width of the streets, and an unprecedented attention, as compared to other parts of the city, to elements regarding pedestrian areas (Capasso 1997). Considering a long-term time frame, the neighbourhood took shape as an area specialized in apparel and footwear (Leone 1986). More specifically, between the 1950s and 1960s, in light of a pervasive building expansion and a consistent increase in population, the Vomero neighbourhood still did not have an adequate commercial presence, that was a distributional network able to satisfy the demand of the residents (Orefice 1986; D’Alessandro 2006). In the Seventies, construction became aggressive and there was another steady demographic increase: the two neighborhoods that are currently a single Municipality became the most emblematic examples of these phenomena throughout the entire city (Piana 1986).

In the short span of just a few years, the Vomero neighbourhood was characterized by the presence of areas specialized in the sales of goods of low purchase frequency, later holding out against the commercial crisis of the Eighties thanks to its specific profile. This profile was actually an alternative to the city center areas and, at the same time, different from that connected to the sale of ordinary goods and goods of mass consumption, typical of neighborhoods in which local shops proliferated (Idem; D'Alessandro 2006, 87). The birth of new shopping arcades contributed to highlighting this difference even more, in the field of retail, as compared to the other parts of urban space ${ }^{9}$ (Leone 1986).

The Nineties consolidated the image of a neighbourhood offering a distinct urban-retail structure, produced both by the specificities acquired in the previous decades, as well as by the progressive innovations, which ranged from the characteristics of the stores located on the most important streets to the shopping arcades and to the fairs that accompanied events. During this dec-

\footnotetext{
to temporary shacks, later transformed into actual shops (La Gala 2004, 256): the commercial evolution of the two streets, although different, even today leads to group them together as the "elegant" streets of the Vomero neighborhood (Vinciguerra 2017, 27).

9 The symbol of the modern shopping arcade was considered the Galleria Vanvitelli, created in the Seventies: while it was a commercial hub due to its central position, it presented some weaknesses (Laureati 1997); these seem to be overcome at least in part, as the fieldwork has shown, thanks to the new types of activities that have recently characterized a sort of rebirth in this place of commerce.
}

ade, interesting innovations in the architectonic elements of the commercial landscape were attempted, mixing with the forms of resistance of historic shops. For example, it is possible to cite some forms of coexistence: the so-called "anodized aluminum phenomenon" (Capasso 1993, 224) - generated by the emphasis of the use of this material, above all for the shop fronts of coffee bars - coexisted with shops that represented traditional elements of urban design ${ }^{10}$.

In this manner, at the beginning of the decade, via Scarlatti - considered a street of average-superior quality, on par with the much more well-known via Toledo offered "both mass consumption and specialized retail" (Ibidem 235-236). Even then, it was considered a street that boasted a combination of retail and strolling about, thanks to its ideal urban position, to the historical and building fabric that was almost completely homogeneous and to the "discontinuous" encroachment of shop basements (Capasso, Pinto 1993). The most consolidated areas of the neighbourhood were described as being characterized by a complex spatial articulation from a functional point of view: they were residential areas adequately equipped with a variety and quantity of facilities and services so much so that they even attracted inhabitants from outlying neighborhoods thanks to their "high-performing" presentation, while the flow of commuters towards the city center, guaranteed by the funicular railways, was substantial for the so-called superior urban goods ${ }^{11}$ (Apreda 1997).

The consequences of semi-pedestrianization in via Scarlatti that began in 1995 (Ibidem 364) and the public debate that followed between those (mainly architects/urban planners), who hoped for the total closing of this street - as well as other streets - to "automotive provincialism" (Capasso, Pinto 1993), and the shopkeepers, who rapidly changed from positions of ostracism to attitudes of consent as to total pedestrianization, contributed significantly to the modification of the commercial hub of the neighborhood, which has continued

\footnotetext{
${ }^{10}$ This is the case of the flower stand located in piazza Vanvitelli since 1907 (Ibidem 231), one of the few businesses over one hundred years old that is included in the municipal register today.

${ }^{11}$ A further development was made by the opening, in several phases, of the subway line n.1, inaugurated in 1993 in piazza Vanvitelli: today the square is connected not only to the city center and to the neighborhoods in the northern part of the city but, due the effect of the interchange with the other subway line and with the funicular railways, also to other areas of Naples and of the hinterland. The popular press often highlights the other side of the coin that this growing connection has led to, underlining the negative consequences produced by the easy access to a public place that appears, moreover, amongst the main areas of city nightlife.
} 
to identify with the area we have investigated ${ }^{12}$. Between the Nineties and the first decade of the new century, other measure were carried out - regarding mobility, creation of pedestrian walkways and restoration of individual stores - that showed the progressive urban-retail centrality of the Vomero neighbourhood, a micro-space that symbolized one of the most virtuous relationships between shopping and taking a walk or one of the ideal places to window shop. A practice, the latter, that seems to be further emphasized with the moving of the neighbourhood towards more pervasive forms of a combination of shopping and entertainment. Above all for some categories of users, as shown also in a research on the relationship between consumer and urban environments in a medium-sized city in Northern Italy (Qualizza 2017), window shopping is driven "by exploratory and recreational motivations, which do not necessarily lead to purchases" (Ibidem 74). The shopkeepers interviewed during our fieldwork made multiple references to practices of this kind, defining them as "entertainment commerce" to exemplify that, especially during the weekend or the holidays, at the neighbourhood scale the need for buying seems to be inseparable from that for leisure.

\section{Fieldwork}

The Vomero neighbourhood still today emerges as a particularly interesting object of study, due to the presence of a mix of characteristics that continue to differentiate it from the dynamics of other neighborhoods of the city that aim towards a high level of commerce. As we stated previously, fieldwork focused on the two streets that symbolize the vitality of retail - via Alessandro Scarlatti (including piazza Vanvitelli) and via Luca Giordano - but also on the adjacent streets that gravitate around these. Overall this historical, central part of the Vomero neighbourhood represents a point of reference for a significantly vast area. Accessibility and organization prove to be two key factors: the center of the neighbourhood, that is a broad area in which it is possible to satisfy all needs, is easily reached and quite vibrant.

In order to explore the characteristics considered less accessible through quantitative data and the media, the fieldwork was initially carried out through in-depth site visits, during various days of the week and at different times, in the belief that the direct observation of

\footnotetext{
12 Via Scarlatti, along with via Alvino and via Merliani, makes up a single Urban Pedestrian Area, instituted with the Deliberation of the City Council 3091/1995 and regulated, with regard to the road traffic, by the Mayoral Ordinance 1241/1999.
}

this location - with the feelings, perceptions, and emotions that it provokes - represents a fundamental starting point of empirical research on retail and consumption $^{13}$. Next, the mapping of the two main streets was carried out, with a survey of the spatial organization of the retail establishments and their typological classification, in order to verify the changes that occurred during the most recent years. Thanks to a dialogue with several actors in local politics, who showed great willingness and interest in this research, some in-depth and semistructured interviews were carried out with a number of privileged witnesses. Through the intermediation of members of the Municipal Administration ${ }^{14}$, it was possible to interact with shopkeepers in the neighbourhood who were selected according to typological characteristics, years of activity and union or association commitments. The interview allowed for the support of the picture that emerged from the site visits and the mapping with thoughts on the role of retail and consumption in the complex dynamics of transformation occurring in the neighbourhood: this appeared even more necessary in light of the Covid-19 health crisis and the consequent lockdown, which began during the last phase of our study.

\section{1 "The city within the city"}

The origins of the commercial diversity of the Vomero, as previously stated, must be searched for in the history of urban development, in which the neighbourhood has been organized in an almost completely independent manner as compared with the rest of the city, mainly thanks to the variety and quality of the commercial and service activities located there. Its commercial success lies on this separateness, as we were able to deduce from the words of an interviewee who described the Vomero as a "city within the city". This distinctive feature is also confirmed by visits to the neighbourhood that, according to the shopkeepers, are mainly carried out by its inhabitants because, as another interviewee underlined: “a resident of the Vomero neighbourhood doesn't leave it, or does so rarely: besides the fact that you can find everything here, a resident tends to consider those who visit it almost like invaders". This refers to the customary presence, during the weekend, of a significant number of users coming from other areas of the city or of

\footnotetext{
13 The fieldwork was carried out from December 2019 to the first week of March 2020

14 Sincere thanks to the City Councillor for Labor, Commerce and Culture of the 5th Municipality, Luigi Sica, and to the City Councillor, Daniele Quatrano.
} 
the province, so much so that the interviews have highlighted a certain reluctance on behalf of the residents, as well as on behalf of some shopkeepers, as to activities - Christmas fairs ${ }^{15}$, confectionary fairs, and food fairs that are periodically organized in the neighbourhood and events (such as the White Night festival), all aimed towards increasing the number of participants ${ }^{16}$. The Vomero, on the other hand, remains principally detached from the dynamics of touristification that, in recent years, have started to involve other retail areas of the city: the neighbourhood, especially if compared to others in the city center, is not currently able to guarantee entertainment alongside a cultural program that would attract large-scale tourist traffic ${ }^{17}$. This, however, has not prevented the recent proliferation of $\mathrm{B} \& \mathrm{Bs}$ and vacation homes, prompted mainly by an excellent transportation network that connects the neighbourhood to the most attractive areas of the city: convenient transportation, together with atmosphere, order and urban decorum seem to make it an exceptional hub for short stays.

In this context, the retail network is in profound and rapid evolution, as the activities of the Centro Commerciale Naturale Vomero-Arenella ${ }^{18}$, founded in 2014 with the goals of the retail enhancement of the area and the struggle against (over)expensive rental prices and racketeering, show ${ }^{19}$. The inclination towards the construction of an avant-garde, sophisticated and highquality commercial landscape - made up of apparel and footwear stores, as well as a significant variety of excellent local products - have given way to innovative projects and formats exported from European experiences, like concept stores or temporary shops or even activities more connected to leisure rather than to purchasing needs. Several shopkeepers did not hesitate to associate

\footnotetext{
15 One of the Christmas fairs enlivened via Luca Giordano precisely when we were doing this research: Sommella, Guadagno 2019 dedicated an in-depth study to it.

16 The White Night, after several disappointing experiments in other parts of the city, was organized for the first time in the Vomero neighborhood in 2012, and for three years it attracted numerous visitors. Not all of the interviewees were contrary to this type of events, rather some considered them fundamental for the development of the area.

17 The Vomero neighborhood is home to several cultural attractions (Sant'Elmo Castle, the Museum and Carthusian monastery of San Martino) and natural attractions (the Villa Floridiana urban park).

${ }^{18}$ The Centro Commerciale Naturale - whose name comes from the desire to act as an alternative to artificial shopping centers - is the Italian variant of Town Centre Management: a network of shops (and sometimes also of craft and tourist services), organized in specific places of commerce in order to propose an integrated offer and often aimed at relaunching commercial areas especially in the city-centres.

19 It must be remembered that, in 1976, there was an initial form of associative activity amongst the shopkeepers called Centro Commerciale Vomero: at the end of the Eighties, the association included over 450 businesses (La Gala 2004, 306).
}

some of the new commercial presences with the transformation of the neighbourhood into a space of consumption based on the combination of "nightlife and shopping sprees". This combination, according to these interviewees, risks depriving the inhabitants of the commercial areas that satisfied their consumption needs, very often connected to historic activities that are disappearing.

The topic of closing historic stores and workshops, which is a common thread in the Vomero neighbourhood and in other parts of the city, is the subject of great debate regarding the transformation of said neighbourhood. In this regard, the owner of a historic shop that is over one hundred years old, referred to a sort of domino effect connected to the strategies of certain companies operating mainly in the fast-fashion field, which - either for commercial prestige or for marketing operations are all located on the same retail streets because they are encouraged dynamic described as follows: "if there are large retail enterprises of this kind, ours cannot partake". Other interviewees, however, expressed favorable judgements as to the new formats, considered as the only ones able to transmit forms of innovation, even hoping for a greater appeal of the retail areas of the neighborhood on behalf of consumers from other parts of the city or from the metropolitan area, or even for more significant tourist traffic. These differing opinions show, as it often occurs in these cases, that the ongoing phenomenon is quite complex: the dialogue with privileged witnesses leads to certain considerations in light of the new urban-retail structure of the neighbourhood.

\subsection{The outpost of Neapolitan retail innovation}

The hub of via Scarlatti is represented by the pedestrianized part, characterized by the concentration of a large number of apparel shops and bars: here the presence of big brands and two department stores transforms the landscape, as the shopkeepers interviewed noted, into a sort of open-air shopping center ${ }^{20}$. Besides being quite visible and easily recognized thanks to the aesthetic quality of the structures, the logos and the indoor and outdoor furnishings, the stores take up large spaces which makes them even more imposing, compared to the stores of smaller dimension, in the overall retail landscape. At the same time, they contribute to significantly differentiating, in terms of the experience

${ }^{20}$ Amongst others, the following stores are present in this section: COIN, Cisalfa, Benetton, Zara, Nike, Harmont \& Blain, D-mail, Kiko, Twinset, Foot Locker, Intimissimi, Timberland, Yamamay, Original Marines, Golden Point, Camomilla, Liu Jo. 
Table 1. Via A. Scarlatti and via L. Giordano: total shops by type. Source: authors' elaboration.

\begin{tabular}{lcc}
\hline Type & $\mathrm{n}$. & $\%$ \\
\hline Apparel & 96 & 31.8 \\
Food\&Drink & 72 & 23.8 \\
Jewelry shops/Silverware shops & 18 & 6 \\
Perfume/cosmetics & 11 & 3.6 \\
Shoes/bags/leather goods & 23 & 7.6 \\
Bookstores & 3 & 1 \\
For rent/for sale & 12 & 4 \\
Other & 67 & 22.2 \\
Total & $\mathbf{3 0 2}$ & $\mathbf{1 0 0}$ \\
\hline
\end{tabular}

of consumption, this section of the street. Another section, though characterized by a frenetic atmosphere due to the traffic, still has the feel of the neighbourhood. One person who has worked for about thirty years in a popular bar, located on this street since the Seventies, highlighted that the clients are mainly locals, affirming: "if it were not for the shops, we probably wouldn't exist, because $80 \%$ of our clients are shopkeepers who, in most cases, are from the Vomero neighbourhood, so they come here outside of working hours". The section closest to piazza Vanvitelli is completely different: the atmosphere here changes and is characterized by bars with outdoor seating - available space and well-maintained urban furnishings - where it is possible to stop before, during, or after shopping or where it is possible to stop and partake in nightlife.

Via Luca Giordano also shows sections that are commercially diversified. A section that was for many years mainly residential with few shops, even though it is not pedestrianized, is today characterized by new bars, typical restaurants and a few important apparel shops. Quite different is the section that, as part of the pedestrianized area, seems to mirror what was was observed in via Scarlatti: large retail chain stores along with bars, quality apparel and footwear shops, but with more contained physical and economic dimension ${ }^{21}$. Even on this street, finally, there is also a section that is tailored to a neighbourhood dimension, fit for residents: this section still has some historic sartorial shops as well as those that are more utilitarian, such as upholstery shops, hardware stores, historic salted codfish shops and even a delicatessen, which make up a setting that would be unthinkable in some of the previously described sections.

\footnotetext{
${ }^{21}$ Amongst others, the following stores are present in this section: Piazza Italia, Sephora, Carpisa, Tezenis, Zuiki, AW LAB, Lovable, Mondadori, Mara Carol, Intimissimi, Paola Riva, Calzedonia, Nara Camicie.
}

Table 2. Via A. Scarlatti and via L. Giordano: food shops by type. Source: authors' elaboration.

\begin{tabular}{llc}
\hline Type & $\mathrm{n}$. & $\%$ \\
\hline Restaurants, pizzerias, pubs & 17 & 23.6 \\
$\begin{array}{l}\text { Bars/ pastry shops/ ice cream } \\
\text { shops }\end{array}$ & 33 & 45.8 \\
Innovative/typical & 11 & 15.3 \\
Local shops & 11 & 15.3 \\
Total & $\mathbf{7 2}$ & $\mathbf{1 0 0}$ \\
\hline
\end{tabular}

Overall, the two retail streets appear as rather heterogenous in terms of supply, with a marked concentration of apparel in the central pedestrianized sections (Tab. 1).

Closures were, in many cases, followed by new openings that seem to adhere to the new consumption habits: from the data collected, the unrented shops and those for sale on both streets represent just $4 \%$ of the overall retail landscape. From this point of view, many new businesses are part of the category food \& drink: with almost $24 \%$ of the total businesses, food according to almost all the interviewees - expresses the emblematic value of the transformation of consumption practices and retail innovation in the area.

Out of 72 food shops surveyed, almost half were part of the category bar/pastry shop/ice cream shop: these are businesses that, in many cases, have large outdoor seating areas (stationary or mobile) that take up considerable surface area (Tab. 2). The significant presence of these shops is more and more in line with the morphology that the area is adopting, especially in the section in which there is a close interdependence between retail and leisure.

The category that we defined as innovative/typical in order to indicate the presence of particular formats is very interesting, in that they are specialized in the sale of specific products or whose target is represented by clients looking for out of the ordinary experiences. Amongst the most emblematic we recall l'Archivio Storico (a cocktail bar with particular furnishings and the concept of Neapolitan history, specifically the Bourbon period) and the Cafè Postal (a coffee shop that is also a private mail service). Sometimes these are "pioneer" activities, born here and then spread to other parts of the city: this is the case of Chipstar, the first store specialized in the sale of Dutch fried potatoes, located for the last six years on the most important retail street in the neighbourhood and then expanded to other parts of the city ${ }^{22}$, and the restaurant Panamar, which opened

22 The Chipstar brand is a franchise created in Naples at the end of 2013, with its first store in via Scarlatti and others in via Chiaia and in via 
two years ago and makes seafood sandwiches, proposing a format imitated in other areas of the city.

While the main streets of the neighbourhood seem to have modified their appearance over a rather long period of time, it is mainly on the side streets that the new businesses have multiplied in the most recent years, as evidence of a consolidated capacity of construction of the retail space that finds its roots in the history of the neighbourhood, which has always been oriented toward innovation and originality. The landscape of these streets has gradually been characterized by the presence of ethnic restaurants (mainly Japanese), sandwich shops, cocktail bars, organic food shops, herbalist shops and similar types of businesses ${ }^{23}$.

Some of the new presences, however, do not always meet with the approval of the shopkeepers interviewed: more than one, while recognizing the particularly original features that the presence of food takes on in the Vomero neighbourhood as compared to the city center, consider the phenomenon the cause of the decline of the retail fabric and, above all, of the closure of many historic shops. In this regard, it must be highlighted that many of these shop owners decided not to join the register for the promotion of businesses instituted by the City of Naples in $2014^{24}$. In some cases, the implementation of innovative businesses allowed for the recovery of commercial sites in decline: a striking example is the Galleria Vanvitelli, which we had cited as a case of desertification and which recently has been revitalized, due to its proximity to the side streets protagonists of the positioning of new types of stores ${ }^{25}$. Growing attention to organic products, an expression of consumption practices different from the past, leads to a reflection on the role played by a certain type of aesthetics, of image,

\footnotetext{
Toledo (which, however, were later closed). The initial success of the format led to openings outside the Campania region, both nationally and internationally.

${ }^{23}$ It is possible to cite various examples: from Healthy, a health store (with a fitness area, cafe-bar, bookstore, cosmetic area, and homeopathic pharmacy) to Poke, a venue specialized in typical Japanese-Hawaiian salads (served in a specific bowl) and another of a large concept store, Riot laundry, that recreates the Anglo-Saxon model of reconverting businesses with industrial furnishings and minimalist decoration (in the Vomero neighborhood it is the premises of the ex-bookstore Loffredo reconverted into a business that is, at the same time, a cafe, cocktail bar, clothing and record store) to Sogni di latte (a cheese shop with a space for tastings that presents a vast assortment of cheeses rarely available elsewhere).

${ }^{24}$ At the end of 2019, just five businesses from the Vomero neighborhood were registered (four in the category historic shops and one in the category businesses active for over 100 years), compared to a presence of this type of activity that is certainly more significant.

${ }^{25}$ In the Galleria Vanvitelli, there is a gym/beauty center that uses the latest equipment, a skater-style clothing store, and a very popular organic supermarket named NaturaSi.
}

of form and of space in a neighbourhood like Vomero, whose inhabitants show a particular awareness of projects that rely on shopkeepers who are attentive to the territoriality of merchandise.

The area studied, overall, from the point of view of the retail offering still shows some heterogeneous characteristics, though in a framework of progressive homogenization mainly produced by the ever-increasing combination of shopping and leisure (Fig. 2).

The heterogeneity, in some cases, represents the product of new shops, even in prevailing sectors (such as apparel and food, which are fairly diversified within their sectors). While some sections of the two main streets tend more and more to conform to those of other retail streets - characterized by a succession of large brand stores in the fashion and beauty sectors, outdoor seating, different types of fast-food, temporary shops, concept stores, restaurants and home decor shops - other sections are characterized by an articulated supply, even in shops that boast numerous years on those streets and are on its inhabitants that, in the Vomero neighbourhood, mostly correspond to a medium-upper social class with a high spending capacity.

\section{Concluding thoughts: renewal and embeddedness}

The recurring image of this neighborhood as a "(modern) city within the city" or "metropolis within the metropolis" (Vinciguerra 2017, 26-27) recalls an autonomy emphasized as a difference especially with regard to the areas of the city center: "the Vomero [neighbourhood] has a separate life, it is almost autonomous. In the neighbourhood, everything needed to study, have fun, eat, is present [...]" (Ibidem 27). The comparison between the two parts of the urban space, in the volume cited, is emblematically symbolized by the coffee shop that is most representative of the Neapolitan tradition (Gambrinus, located in piazza Trieste e Trento) in the touristic center of the city and the gritty American coffee shop (Cup Cap's Coffee, located near the Central Funicular) in the Vomero neighbourhood. It is not possible here to reflect on this comparison and on the interpretative instruments utilized to carry it out: it is enough to underline that, from the cited research, the Vomero emerges as a location in which "consumption is overshadowed by other things to do" (Ibidem 90). The latter is an element also mentioned by the interviewees during our fieldwork in relation to that which they indicate as "entertainment commerce", which has as protagonists those who consume in the neighbourhood or the neighbourhood itself, not just as patrons. 


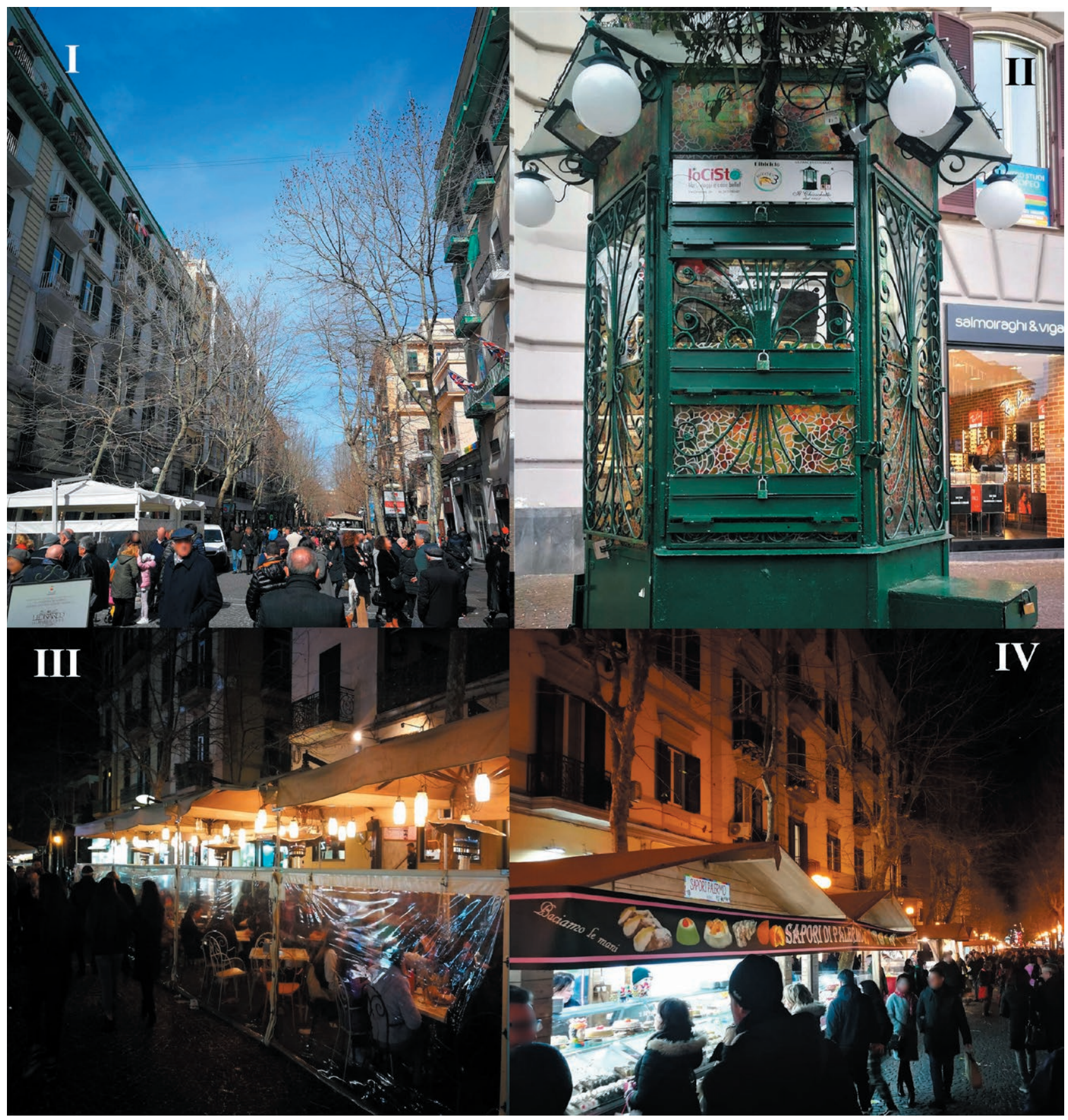

Figure 2. I) Commercial street: shopping and walking; II) An over 100-year-old stand; III) Outdoor aperitif; IV) Food festival in front of the shops. Source: D’Alessandro, Autiero 2020.

According to the privileged witnesses, if the progressive autonomy acquired with respect to the rest of the city did not protect the Vomero neighbourhood from forms of homogenization of its urban-retail fabric, it is partially because these forms are expression of tastes and lifestyles not only of those who utilize the Vomero neigh- borhood, but also of those who inhabit $i^{26}$. From this point of view, the "vomeresità", that is to say the qual-

${ }^{26}$ While it seems excessive to speak of McDonaldization, it is true that in this neighborhood is localized a fast-food restaurant of this chain like of the aforementioned Chipstar -, incidentally in the area we investigated. 
ity of hailing from the Vomero neighbourhood (La Gala 2004,8 ), is reflected in as many forms of belonging as there are consumers (residents or users) of the products sold in the neighbourhood, or how many of them still utilize the neighbourhood as a place of consumption.

At the scale of its polarizing hubs, retail and consumption create and recreate "place-specific identities" (Crewe, Lowe 1995, 1878), that more and more often come into conflict amongst themselves. As effectively underlined by some interviewees, the old pioneers have become staunch defenders of an embeddedness made up of resistance of historic shops, neighbourhood stores and of a retail offer connected to traditional cultural opportunities. A vision that clashes with that of the new pioneers (that sometimes are both new retailers and new inhabitants), who express requests in support of various forms of innovation, both in terms of the combination of shopping and leisure, as well as in new hybrid formats that combine economic and cultural elements, with food as the new protagonist in a myriad of forms.

In this tension between forms of renewal and embeddedness, the fieldwork highlighted an initial element of contention as to the commercial hub and the area we investigated: that between old and new inhabitants, which shows individual and groups that assert different and contrasting forms of territorialization of retail and consumption practices. In this case, it is a very different dynamic with respect to those of other neighborhoods of the city and that, only occasionally, reveals early stages of retail gentrification ${ }^{27}$. Said retail gentrification, in a context that still reports elements of heterogeneity even in the cooler sections of the main streets, seems to reflect patchworklike phenomena attributable to the predominance acquired from the tastes and lifestyles of those who have greater economic capital rather than cultural capital; however, it is not possible to exclude that, over time, this could be also associated with more pervasive forms of gentrification. From this point of view, according to several interviewees, the staunch defense of the "vomeresità" of the past may become a bastion of advancement for the more homogenized forms of the retail landscape. Said landscape, besides representing the advent of new shops and new actors, is also the fruit of a change in atmosphere generated by the adaption of the current shops into ways to attract new clientele through an upgrading up their merchandise and their ambiance, as Zukin revealed in her New York study (Zukin et al. 2009). Such dynamics produce nega-

\footnotetext{
${ }^{27}$ Early stages both because they are not connected to complex questions of social class, ethnicity and cultural capital - which go far beyond the individual neighborhoods and urban spaces - and because they do not produce forms of displacement of the current residents or social inequality, which occurs in global cities (Zukin et al. 2009, 48).
}

tive effects that mainly affect the so-called "neighborhood shops" and that - even in an urban context completely different then the one just mentioned in terms of size, characteristics and range of the commercial function - can produce pervasive consequences in terms of abandonment on behalf of some consumers (mainly, but not limited to, residents), induced by the impossibility to satisfy demand that was guaranteed in the recent past by activities linked to the urban fabric. A second element of contention in our area of study is that which contrasts inhabitants and users, with the latter who assert their prerogatives at night, especially during the weekend ${ }^{28}$. In this case, it is a dynamic more in line with what occurs in other parts of the city with a new centrality acquired by street food.

It is not to be underestimated that both contentions face a reality different from that which characterizes the globalization of consumption in other urban contexts: the Vomero neighbourhood is not a touristic-commercial area upgraded through top-down urban planning that have turned into outright forms of gentrification. Still, the neighbourhood experiments localization strategies regarding brands or chain stores in cooler sections and encounters fundamental leverage in new entrepreneurs, who often express their location preference for this micro-space because they consider it the outpost of progressive innovations.

Framed in these terms and associated with the statements obtained from the discussion with the local community, the specific interaction between global and local elements (Crewe, Lowe 1995, 1878) calls into question the need to anchor the current changes to policies, starting with the existing ones - which have often been implemented without considering processes that have already occurred - until those that have never been realized. It is not a question of deciding which element - renewal or embeddedness - should identify the neighbourhood, its inhabitants or its users, but rather of identifying a more virtuous relationship between changes in retail and consumption practices. This because, in a micro-space in which the continuous search for novelty and various forms of resistance to change oppose each other, our research shows several risks of disintegration of a fabric in which retail and consumption, understood as identity-related elements of territorial belonging ${ }^{29}$, still represents fundamental components.

\footnotetext{
${ }^{28}$ In many cases, the protagonists are young people: for an in-depth study of the role that they play in consumption spaces during nighttime, see D’Alessandro, Martinez-Rigol 2018.

${ }^{29}$ It is enough to consider that, during the mid-2000s, local newspapers defined the closure of some historic shops - that gave way to shopkeepers "without a track record" or to large chain stores - as "scars in the city's commercial fabric” (Capua 2005).
} 


\section{References}

Apreda, I. (1997). Lo spazio pedonale nel contesto urbano. In Capasso, C. (Ed.). Camminare e vedere. Un concetto, un patrimonio, una filosofia di progetto. Napoli, Prismi, 69-80.

Bell, D., Jayne, M. (2004). City of Quarters: Urban Villages in the Contemporary City. Aldershot, Ashgate.

Capasso, A. (1993). Il Centro Storico. In Capasso, C. (Ed.), Commercio e città. Lo spazio commerciale e lo scenario urbano. Cultura e progetto. Napoli, Cuen, 207-258.

Capasso, A. (1997). Il patrimonio pedonale a Napoli. Una risorsa da rigenerare. In Capasso, C. (Ed.). Camminare e vedere. Un concetto, un patrimonio, una filosofia di progetto. Napoli, Prismi, 249-308.

Capasso, A., Pinto, V. (1993). Indicazioni di progetto per i luoghi del commercio. In Capasso, C. (Ed.). Commercio e città. Lo spazio commerciale e lo scenario urbano. Cultura e progetto. Napoli, Cuen, 359-412.

Capua, P. (2/9/2005). Vomero, addio ai negozi storici. La Repubblica Napoli, https://ricerca.repubblica.it/repubblica/archivio/repubblica/2005/09/02/vomero-addio-ainegozi-storici.html, last accessed on 7/5/2020.

Carreras, C., D'Alessandro, L. (2017). Un repertorio bibliografico su commercio, consumo e città. In Viganoni, L. (Ed.). Commercio, consumo e città. Quaderno di lavoro. Milano, Franco Angeli, 27-69.

Crewe, L., Lowe, M. (1995). Gap on the map? Towards a geography of consumption and identity. Environment \& Planning A, 27, 1877-1898.

D’Alessandro, L. (2006). Commercio e dinamiche urbane: il centro storico di Napoli. Storia Urbana, 113, 77-97.

D’Alessandro, L. (2012). Geografia del commercio. In Lessico del XXI secolo. Roma, Istituto dell'Enciclopedia Italiana Treccani, 508.

D’Alessandro, L., Martínez-Rigol, S. (2018), Consumando spazi centrali e notti urbane: micro-geografie dei giovani a Barcellona e a Napoli. Bollettino della Società Geografica Italiana, 14, 1 (2), 163-176. DOI: 10.36253/bsgi-vli2.533

La Gala, A. (2004). Vomero. Storia e Storie. Napoli, Guida.

Laureati, M.L. (1997). Portici e gallerie. In Capasso, C. (Ed.). Camminare e vedere. Un concetto, un patrimonio, una filosofia di progetto. Napoli, Prismi, 137-146.

Leone, U. (1986). Un'immagine per il commercio. Orizzonti economici, 52, 5-7.
Lowe, M., Wrigley, N. (2000). Retail and the Urban. Urban Geography, 21 (7), 640-653.

Orefice, M. (1986). Sviluppo urbanistico ed evoluzione del commercio. Orizzonti economici, 52, 25-40.

Pfirsch, T. (2011). La localisation résidentielle des classes supérieures dans une ville d'Europe du Sud. Le cas de Naples. L’Espace géographique, 40 (4), 305-318. DOI:10.3917/eg.404.0305

Piana, R. (1986). Considerazioni sul fenomeno commercio. Orizzonti economici, 52, 41-42.

Qualizza, G. (2017). Storytelling e shopping experience: pratiche di consumo e strategie narrative in un centro urbano. Synergies Italie, 13, 67-79.

Sommella, R., Guadagno, E. (2019). Spazi e tempi del commercio su aree pubbliche. In Viganoni, L. (Ed.). Commercio e consumo nelle città che cambiano. Napoli, città medie, spazi esterni. Milano, FrancoAngeli, 427-477.

Viganoni, L. (Ed.). (2017). Commercio, consumo e città. Quaderno di lavoro. Milano, FrancoAngeli.

Viganoni, L. (Ed.). (2019). Commercio e consumo nelle città che cambiano. Napoli, città medie, spazi esterni. Milano, FrancoAngeli.

Vinciguerra, V. (2017). Dall'autenticità alla "McDonaldizzazione" di Napoli: confronto tra storia e modernità di due realtà partenopee. Varazze, PM Edizioni.

Zukin, S. et al. (2009). New Retail Capital and Neighbourhood Change: Boutiques and Gentrification in New York City. City \& Community, 8 (1), 47-64. 